\title{
Marine Algae from Black Sea - Important Resources in the Pharmaceutical and Medical Research
}

\author{
Emin CADAR \\ UMF Carol Davila Bucharest, Faculty of Pharmacy, Bucharest, Romania \\ Cristina-Luiza ERIMIA \\ Ovidius University of Constanta, Faculty of Pharmacy, Constanta, Romania \\ Aneta TOMESCU \\ Ovidius University of Constanta, Faculty of Medicine, Constanta, Romania \\ Stelian PARIS \\ Ovidius University of Constanta, Faculty of Pharmacy, Constanta, Romania \\ Rodica SîRBU \\ Ovidius University of Constanta, Faculty of Pharmacy, Constanta, Romania
}

\begin{abstract}
During the past years, it became obvious that the ecosystem presents a marine algae surpluses, which should be turned valuable in one way or another. The importance of the macrobenthic flora - algae and phanerogammes - for the general productivity of the marine environment, especially in shallow waters, is becoming more and more obvious from the biological as well as from the economical point of view. The macrophytes also represent a particular life form. The benthic macroflora includes 33 species 4: 16 Chlorophyta, 10 Rhodophyta, 5 Phaeophyta, and 2 Phanerogama. The quantity of green algae (Chlorophyta) was higher in the Constanta Eforie area, as red algae are predominant in the southern part of the littoral. Brown algae (Phaeophyta) were encountered in the Constanta city area (Punctaria) and in Vama-Veche (Cystoseira barbata). Yet, this fact indicates a slight amelioration of the marine ecosystem, after many years of eutrophication. The superior capitalisation of the marine biomass represents a highly important resource for the pharmaceutical industry, supplying raw material for the extraction of bioactive substances and various other substances, the purity of which is strongly connected to the state of the marine ecosystem.
\end{abstract}

Keywords: marine algae, Chlorophyta, Rhodophita, Phaeophyta, Phaeophyta

\section{Introduction}

The importance of the macrobenthic flora - algae and phanerogames - for the general productivity of the marine environment, especially in shallow waters, is becoming more and more obvious from the biological, as well as from the

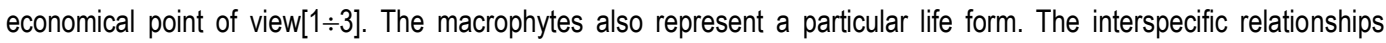
between the benthic macro- and microphytes, as well as the relationship between these and the associated fauna ensure the existence of a wide interspecific type of relationships. Yet, this fact indicates a slight amelioration of the marine ecosystem, after many years of eutrophication. The superior capitalisation of the marine biomass represents a highly important resource for the pharmaceutical industry, supplying raw material for the extraction of bioactive substances (vitamins, sterols, and collagen) and various other substances, such as agar-agar, the purity of which is strongly connected to the state of the marine ecosystem. 


\section{Research Methods}

In 2012 it was conducted the qualitative and quantitative analysis of phytobentic samples on a range of 75 samples collected during the summer season. The samples were taken from profiles and stations considered representative in terms of algal flora and follow the coastline: Năvodari, Constanta Casino, Eforie Nord, Eforie Sud, Tuzla, Costineşti, Mangalia, 2 Mai and Vama Veche[1]. Following the qualitative analysis, in summer 2014 were identified 20 taxa assigned to filums as follows: 9 species belonging to the phylum Chlorophyta, 1 species - phylum Phaeophyta (Cystoseira barbata), 8 species belonging to the Rhodophyta phylum (7 species and a variation, respectively Ceramium rubrum var. barbatum) [3]. In 2014 in view of the monitoring of the Black Sea water quality there were investigated the physico-chemical indicators. They were obtained from the analysis of surface water samples and of the water column $(0-20 \mathrm{~m})$ collected during two oceanographic expeditions (in May and November), from two stations situated on 5 and $20 \mathrm{~m}$ isobath[2] . There were analysed the main physical - chemical and status indicators that characterize and control the eutrophication level, namely: salinity, $\mathrm{pH}$, dissolved oxygen, inorganic nutrients. The salinity was measured in-situ. The dissolved oxygen was determined by the Winkler method. The $\mathrm{pH}$ was measured by the potentiometric method. The nutrients in seawater were quantified by analytical spectrophotometric methods, internally validated in the laboratory with reference to the textbook "Methods of Seawater Analysis" [4] The benthic macroflora included 33 species [5]: 16 Chlorophyta, 10 Rhodophyta, 5 Phaeophyta, 2 Phanerogama. The quantity of green algae (Chlorophyta) was higher in the Constanta - Eforie area, as red algae are predominant in the Southern part of the littoral. Brown algae (Phaeophyta) were encountered in the Constanta city area (Punctaria) and in Vama-Veche (Cystoseira). During the past years, it became obvious that the ecosystem presents a marine algae excess, which should be turned valuable in one way or another. The following species stand out: Cladophora vagabunda (L.), Enteromorpha intestinalis (L.), and Ulva Lactuca Species (Ulvae rigida). From the read and brwoun algae we have Ceramium rubrum and Cystoseira barbata. From the green algae of the Black Sea, the systemic clasification of the Class Chlorophyceae was presented [5,6,7]. The methods are from botanical phytochemical and physico-chemical area.

\section{Results and Discussions}

It resulted that algal biomass grew abundantly in summer 2012 as a result of favourable environmental conditions (respectively, high temperature water, amount of nutrients, photosynthesis transparency favorable to photosynthesis). Among green algae, Cladophora vagabunda $\left(1.800 \mathrm{~g} / \mathrm{m}^{2}\right.$ fresh biomass) and Cladophora sericea $\left(1.700 \mathrm{~g} / \mathrm{m}^{2} \mathrm{bp}\right)$ and from the red algae - Ceramium rubrum var. barbatum (approx. $1,000 \mathrm{~g} / \mathrm{m}^{2} \mathrm{~b} . \mathrm{p}$.) developed high biomass. These species were identified during the whole summer season, both in samples and in storage on shore, particularly in the northern part of the coast, because in the southern part prevailed specimens of Ulva (Ulva lactuca - $1200 \mathrm{~g} / \mathrm{m}^{2} \mathrm{~b} . \mathrm{p}$., Ulva intestinalis $770 \mathrm{~g} / \mathrm{m}^{2}$ b.p.) as associated species for Cystoseira barbata fields existing in these areas. [1,3]. Fresh medium biomasses for quantitative dominant groups between 2005-2012 (summer seasons).[1].

In 2014 it can be noted the dominance of opportunistic green algae in the northern sector of the Romanian seaside and the presence of brown algae Cystoseira barbata in Mangalia, 2 Mai and Vama Veche, where it is known that marine waters have a higher quality, which allowed the rehabilitation and the existence of this key marine species for the marine ecosystem (Fig.1). In Mangalia during the summer there were observed Cystoseira barbata well-developed shrubs, epiphytic vagabunda of Cladophora, Ceramium diaphanum var. elegans and Callithamnion corymbosum. The fresh biomass recorded by it was raised $\left(4300 \mathrm{~g} / \mathrm{m}^{2} \mathrm{~b}\right.$.p.), similar to that reported in the previous year $\left(4700 \mathrm{~g} / \mathrm{m}^{2} \mathrm{~b}\right.$.p.), which shows that this species maintain a stable direction of development in this area. In 2 Mai, on a rough rugged substrate, it is found a field of Cystoseira (between 1-3m deep) well developed, with tall Cystoseira barbata specimens, epiphytic generally by small specimens of Ceramium virgatum, at the base of the tals being encountered Ulva lactuca, the dominant species associated to the field. On the elastic surface of the tals were present mussels, which draws attention on the great importance of this perennial brown algae for the ecosystem, as a species that provides life for other organisms. Vama Veche is known from the previous studies as being the area where Cystoseira barbata forms a vast field (between 1-3m) with mature specimens and rich associated fauna. 
Fig. 1: The taxonomic composition of the Romanian sector

Black Sea phytoplankton in 2014 [2]

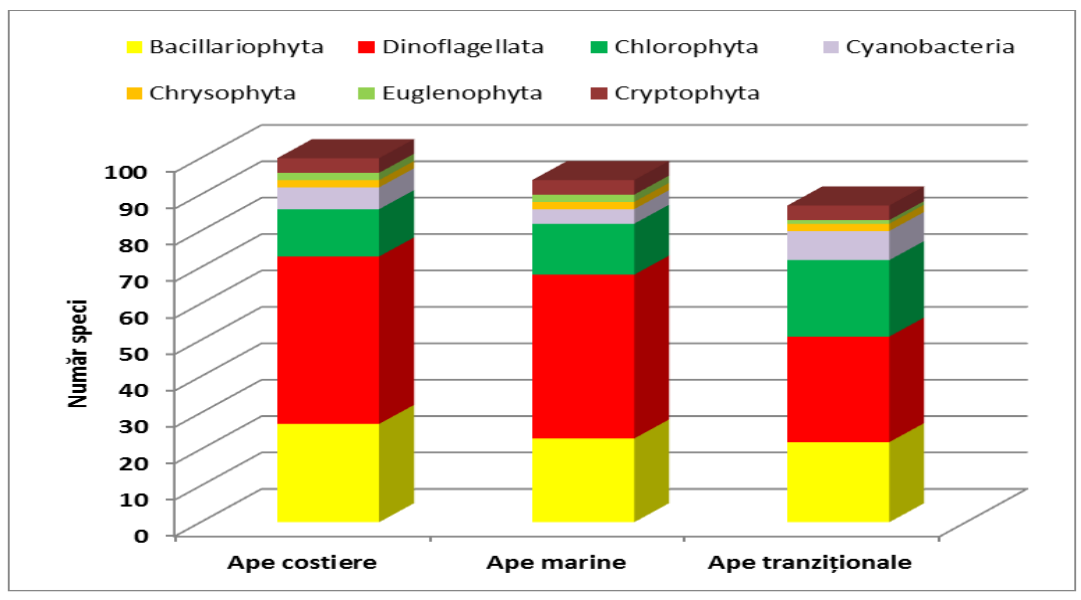

Likewise, in Vama Veche was observed the presence of red algae Corallina officinalis. In the south of the coast, the biomass of the opportunistic species were reduced more compared to other analyzed areas, areas where the perennial species Cystoseira barbata stood out [3]

The salinity recorded homogeneous values between 15.94 to $18.53 \mathrm{PSU}$, specific values for the brackish waters of the Black Sea. The higher values were recorded offshore, in the water column (Vama Veche station 20m), during spring, due to shaping the thermocline and stratification of water bodies. In autumn, the stratification is not visible, the salinity being homogeneous in the water column. The pH values were in the range of 8.20 to 8.55 , normal values, falling within the limits accepted by the Order No.161 / 2006 (The normative concerning the classification of surface waters in order to determine the ecological status of water bodies ) namely 6,5-9,0. In general, a good water oxygenation was observed in the studied area. In spring, in the surface layer was revealed the photosynthetic production of oxygen, the saturation values being within the range from 103.1 to $124.2 \%$. In autumn, the values were homogeneous throughout the water column, slightly lower at the water-sediment contact area (80\%). There were no hypoxia phenomena recorded, all values being within the accepted limit of Order no. 161/2006. The nutrients usually registered normal values, specific to the variability domain specific to the area. During spring, were recorded high values of the phosphates $(1.87 \mu \mathrm{M})$ and ammonium concentration $(17.43 \mu \mathrm{M})$ at surface. The concentrations of phosphate $\left(\mathrm{PO}_{4}\right)^{3-}$, showed concentrations ranging from $0.06 \mu \mathrm{M}$, and 1.87 $\mu \mathrm{M}$. Except the surface value, measured in dots during spring, the other values are low, compared to the 1960's results, reference period for good water quality status of the Romanian coast. The nitrates concentrations (NO3) - varied between 0.04 and $0.93 \mu \mathrm{M}$, very low values that do not exceed the maximum concentration permitted by Order no. 1061/2006, or $1.5 \mathrm{mg} / \mathrm{dm} 3(107.14 \mu \mathrm{M})$. Generally, it was observed a homogeneous distribution of nitrates throughout the water column with slightly higher values during fall when, with the decrease of the biological activity, the nutrients stock began to recover. Nitrites (NO 2), intermediate redox process forms involving inorganic nitrogen species reported low concentrations in the range $0.13-0.95 \mu \mathrm{M}$. All values fall within the maximum allowed by Order no. 161/2006 respectively $0.03 \mathrm{mg} / \mathrm{dm} 3(2.14$ $\mu \mathrm{M})$. The ammonium $\left(\mathrm{NH}_{4}\right)^{+}$, the polyatomic ion in which the nitrogen has the maximum oxidation number, +3 , is the most easily assimilable form of inorganic nitrogen. Its concentrations showed values ranging from 0.51 to $17.43 \mu \mathrm{M}$. The maximum value was recorded in May at surface near the shore and it exceeds the accepted limit for both ecologic status and the impact area of the anthropogenic activity in Order no. $161 / 2006-0.1 \mathrm{mg} / \mathrm{dm}^{3}(7.14 \mu \mathrm{M})$. The silicates, $\left(\mathrm{SiO}_{4}\right)^{4-}$, had low concentrations situated within the range $4.8-10.2 \mu \mathrm{M}$. The highest values were determined in the water-sediment contact area during spring, as a result of the stratification of the water masses. Regarding the contamination indicators in the marine reservation area Vama Veche - 2 Mai, in 2014, the polychlorinated biphenyls and the majority of organochlorine pesticides had, in water, values below the detection limit.

The macroscopical examination for marine algae was realized, which represents the first stage in the investigation of the known or untested vegetal products. This was done through the examination of the entire plant (rizoid, celluloid and filoid), with the human eye, as well as with a magnifyong glass, in order to observe its aspect, dimensions, colour, taste 
and smell $[4,5]$. The microscopic exam of the collected algae was realized through the use of specific for the pharmacobotanical researches, $[5,6]$. For the global chemical analysis, the extraction of the active principles is very important $[6,7,8]$. The qualitative chemical analysis involves the successive and selective analysis of the vegetal products, using solvents with opposing polarities, and the separation by the means of chemical methods, followed by specific reactions which help to identify different groups of active principles or certain chemical constituents [7].

Out of the vegetal sample sprinkled with a non-polar solvent (ethylic ether, petroleum ether, benzene, hexane, clorophorm etc), then with a medium polarity solvent (ethanol, methanol) and only in the ned with water, the following fractions were obtained, $[6,7,8]$ :

- $\quad$ etheric extractive solution $(A)$

- alcoholic extractive solution (B)

- $\quad$ water based extractive solution (C)

Each extract is the analysed for the identification of the active principles of pharmaceutical interest. For the identification of the chemical compounds of the three extracts, they are analysed separately, using the methods fit for the physical and chemical properties of each group of active principles. In the etheric extract we can identify lipophyle chemical compounds, and in the other two extracts hydrophyle chemical compounds.

As a follow up of the identification reactions previously discussed, the following results were obtained, summarized in Table $1,2,3,4$.

Table 1The selective reactions used in chemical analysis and identified active principles from seaweeds

\begin{tabular}{|l|l|l|}
\hline Analyzed solution & Reactions used & Identified active principles \\
\hline Etheric extracts & Lieberman-Burchard & Steroles and triterpenes \\
\cline { 2 - 3 } & Fluorescent UV. $(\lambda=365 \mathrm{~nm}$ & Cumarines \\
\hline \multirow{5}{*}{ Alcoholic extracts } & Iron Chlorure reaction & Catehic Tanin \\
\cline { 2 - 3 } & Fehling & Reducing compounds \\
\cline { 2 - 3 } & Liebermann Bourchard & Triterpenic heterozides \\
\cline { 2 - 3 } & Borntrager & Antracenozide \\
\cline { 2 - 3 } Water based extracts & UV $(\lambda=365 \mathrm{~nm})$ & Cumarines \\
\hline & Fehling & Reducing compounds \\
\cline { 2 - 3 } & $\mathrm{H}_{2} \mathrm{SO}_{4}$ conc. + tymol & Ozes and poliozes \\
\cline { 2 - 3 } & $\mathrm{Foaming}$ & Soapozides \\
\cline { 2 - 3 } & $\mathrm{FeCl}_{3}$ & Catehic tanin \\
\hline
\end{tabular}

In etheric solution $(A)$ :

- a fraction of the etheric extract was evaporated up to dryness; the residuum obtained was dissolved in alcohol - the resulting solution does not have the specific smell of volatile oils for any of the algae species;

- the residuum obtained from the evaporation of the etheric extract was processed with $\mathrm{HCl} 2 \%$; the solution undertook the Mayer and Bertrand reactions; the reactions were negative; the analyzed algae do not contain basic alcaloids;

- $\quad$ the residuum obtained from the evaporation of the etheric extract was processed with methilic alcohol; the alcoholic solution undertook the Shibata reactions; the reaction was negative for all algae species, which do not contain flavonoic aglicones

- the residuum obtained from the evaporation of the etheric extract was processed with amonium hydroxyde; the Borntrager reactive did not colout the solution orange; the analyzed algae do not contain endemoles;

- $\quad$ the Lieberman - Burchard reaction on the etheric extract was positive, indicating the presence of steroles and triterpenes in all analyzed algae;

- the Carr - Price reaction was positive, thus they contain carotenoids, for the species Cladophora vagabunda, Ulva rigida, and negative for the other species;

- the residuum obtained from the evaporation of the etheric extract was processed with amonium hydroxyde; the solution did not present an intense fluorescence on UV radiation, thus no species contains cumarines. 
Table 2 The active principles traced as a follow up of chemical analyses on the etheric extracts

\begin{tabular}{|c|c|c|c|}
\hline The seaweed species & Analyzed solution & Steroles and triterpenes & Cumarines \\
\hline Cladophora vagabunda & \multirow{5}{*}{$\begin{array}{l}\text { Etheric } \\
\text { extracts }\end{array}$} & ++ & ++ \\
\hline Enteromorpha intestinalis & & ++ & ++ \\
\hline Ulva lactuca & & ++ & ++ \\
\hline Cystoseira barbata & & ++ & - \\
\hline Ceramium rubrum & & ++ & - \\
\hline
\end{tabular}

In non-hydrolized alcoholic solution (B):

- $\quad$ the reaction withe the Styassny was negative;

- the reaction with iron chlorure is dark green, thus positive form catehic tanin for the Cladophora vagabunda, Enteromorpha intestinalis, Ulva rigida, Cystoseira barbata species, and negative for Ceramium rubrum;

- In hydrolyzed alcoholic solution:

- $\quad$ through the Fehling reaction, a brick-red precipitate was obtained for all species. Reducing compounds are present in all specie;

- the reaction with ninhydrine of the water based solution obtained from the residuum of alcoholic solution was positive for Cladophora vagabunda, Enteromorpha intestinalis şi Ulva rigida, which cotain aminoacids, and negative for Cystoseira barbata, Ceramium rubrum:

- the residuum obtained through the evaporation of the non-hydrolized alcoholic solution is processed with a water based solution of $\mathrm{HCl} 2 \%$, then turned alcaline with amonium hydroxyde and extracted with ether; after the evaporation of the etheric solution and the recuperation of the $\mathrm{HCl} 2 \%$ residuum, the Mayer and Bertrand reactions are done; the reactions were negative for all the species. The analyzed specie do not contain salt alcaloids.

- the residuum obtained after the evaporation of the alcoholic hydrolized solution is processed with $50 \%$ methilic alcohol; the Shibata reaction on alcoholic solution was negative for all the species; none of the algae analyzed contains flavonozides;

- $\quad$ the Liebermann - Bourchard reaction on the residuum of the alcoholic hydrolized solution caused a green-violet coloration, thus it signalled the presence of triterpenic heterozides in Cladophora vagabunda, Enteromorpha intestinalis şi Ulva rigida ;

- $\quad$ the Borntrager reaction was negative for all species. Antracenozides lack in all species.

- The acid solution is dark brown and does not indicate the presence of antocianozides in any of the species;

- The solution becomes fluorescent under UV radiations, thus cumarines are present in Cladophora vagabunda, Enteromorpha intestinalis and Ulva rigida ;

Table 3 The active principles traced as a follow up of chemical analyses on the alcoholic extracts

\begin{tabular}{|c|c|c|c|c|c|c|}
\hline The seaweed species & $\begin{array}{l}\text { Analyzed } \\
\text { solution }\end{array}$ & $\begin{array}{l}\text { Catehic } \\
\text { Tanin }\end{array}$ & $\begin{array}{l}\text { Reducing } \\
\text { compounds }\end{array}$ & $\begin{array}{l}\text { Triterpenic } \\
\text { heterozides }\end{array}$ & $\begin{array}{l}\text { Antracen } \\
\text { ozide }\end{array}$ & Cumarines \\
\hline Cladophora vagabunda & \multirow{3}{*}{$\begin{array}{l}\text { Alcoholic } \\
\text { extracts }\end{array}$} & ++ & ++ & ++ & ++ & ++ \\
\hline Enteromorpha intestinalis & & ++ & ++ & ++ & ++ & ++ \\
\hline Ulva lactuca & & ++ & ++ & ++ & ++ & ++ \\
\hline Cystoseira barbata & & ++ & ++ & - & - & - \\
\hline Ceramium rubrum & & ++ & ++ & - & - & - \\
\hline
\end{tabular}

In the water based extractive solution (C):

- The reaction for the identification of starch (with Lugol reactive) was positive for Cladophora vagabunda, Enteromorpha intestinalis şi Ulva rigida;

- We have obtained a flaky precipitate - poliuronides present in Cladophora vagabunda, Enteromorpha intestinalis and Ulva rigida; 
- The Fehling reaction was positive for all the species analyzed - reducing compouds are found in all analyzed species;

- The water based extractive solution evaporates into residuum, adding a few drops of concentrate sulphuric acid and tymol alcoholic solution - there results a red coloration, which demonstrates the presence of ozes and poliozes in all analyzed species;

- The foaming reaction of soapozides was negative; soapozides lack in all analyzed species

- The water based extractive solution reacts with diluted $\mathrm{FeCl}_{2}$ and a dark green coloration emerges, which confirms the presence of catehic tanin in all species, except Ceramium rubrum;

- $\quad$ the Mayer şi Bertrand reactions were negative - basic alcaloids lack in all analyzed species.

Table 4 The active principles traced as a follow up of chemical analyses on the water based extracts

\begin{tabular}{|l|l|l|l|l|l|}
\hline The seaweed species & $\begin{array}{l}\text { Analyzed } \\
\text { solution }\end{array}$ & $\begin{array}{l}\text { Reducing } \\
\text { compounds }\end{array}$ & $\begin{array}{l}\text { Ozes and } \\
\text { poliozes }\end{array}$ & Soapozides & $\begin{array}{l}\text { Catehic } \\
\text { tanin }\end{array}$ \\
\hline Cladophora vagabunda & \multirow{2}{*}{$\begin{array}{l}\text { Water based } \\
\text { extracts }\end{array}$} & + & + & ++ & + \\
\cline { 4 - 7 } & & + & + & ++ & + \\
\cline { 5 - 7 } & & + & + & ++ & + \\
\hline Ulva lactuca & & + & + & - & + \\
\hline Cystoseira barbata & & + & + & - & + \\
\hline Ceramium rubrum & & & & & + \\
\hline
\end{tabular}

\section{Conclusion}

The general conslusions of the studies are the following:

As a follow up of the pharmaceutical studies, we have identified and dosed compounds such as flavonoic aglicoles, cumarines, streroles and triterpenes, which are valuable active principles for the pharmaceutical industry.

In addition, we have identified ozes and poliozes, catehic tanin and reduction compounds.

The results obtained enhance the possibility of opening new directions in the process of valorification of the resources offered by the Black Sea, in the research of medicines produced from natural resources.

\section{Acknowledgement}

This paper is supported by the Sectoral Operational Programme Human Resources Development (SOP HRD), financed from the European Social Fund and by the Romanian Government under the contract number POSDRU/187/1.5/S/156040/

\section{References}

[1] ${ }^{* * *}$ Raport național privind starea mediului pentru anul 2012, Cap.5. Protecția Naturii și Biodiversitatea, Agenția Națională pentru Protecția Mediului, Bucarest 2013

[2] ${ }^{\star * \star}$ Raport național privind starea mediului pentru anul 2014, Agenția Națională pentru Protecția Mediului, Bucarest 2015

[3] R. Sirbu, T. Zaharia, A. M. Bechir, G. Lilios, S. Nicolaev , F. N. Roncea, Important Characteristics of the Marine Environment of the Romanian Littoral Coast -Favourable for Pharmaceutical Utilisat ions, Journal of Environmental Protection and Ecology,2012, 13, No 3A, 1842-1855

[4]Klaus Grasshoff, Klaus Kremling, Manfred Ehrahaedt, "Methods of Seawater Analysis" THIRD, Completely Revised and Extendet Edition, Wiley-VCH, Weinheim,new York, Chichester SingaporevToronto, 1999.

[5]Bruneton I. - Pharmacognosie, Phytochimie, Plantes Medicinales, Technique et Documentation - Ed. Lavoisier, Paris 1993, (pag 218, 249, 258, 498, 690);

[6] Peterfi S., lonescu Al., „Tratat de algologie”, 1976-1981, Vol. I-IV, Editura Didactică şi Pedagogică, Bucureşti. 
[7] Sîrbu R., Zaharia T., Negreanu-Pîrjol B.S, Nicolaev S., Bologa A.,Psegalinschi I, The Black Sea ecosystem important potential source for pharmaceutical industry, Journal of Environmental Protection and Ecology, 11 (4): 1336-1348, 2010,

[8] Ciulei I., Istudor V., Palade M., Albulescu D., Gârd C. E. - The Pharmacognostic and Phytochemical Analysis of Vegetal Products - Tehnoplast Company, Bucureşti 1995, vol. I., (pag. 4 -22, 78 - 82, 83 - 86, 96 - 100, 141 146, 221 - 227); and vol. II, (pag. 409 - 418); 